\title{
The importance of lament in pastoral ministry: Biblical basis and some applications
}

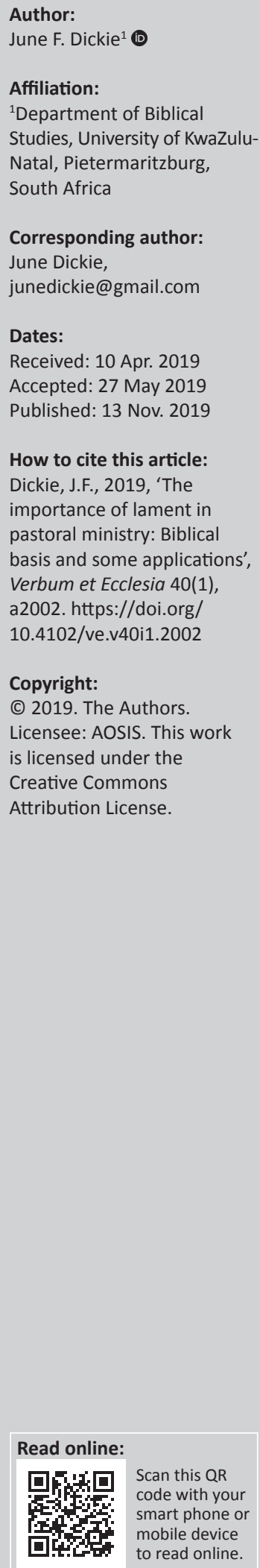

Lament is little understood or practised in most contemporary church communities. However, in today's world of increasing trauma, this means of grace is much needed. In this article, after providing a biblical basis for lament, focus is given to practical applications of lament in various communities. The studies included refugees from the Democratic Republic of Congo and Burundi living in Cape Town, 'discipleship groups' in two townships of Cape Town and an AIDS-support group near Pietermaritzburg. The empirical studies use biblical literature (mainly psalms of lament) either to provide a voice for those who battle to express their pain or to provide a model for sufferers to compose their own laments. Results show that biblical lament can help the individual find healing (social, physiological and spiritual), promote a more socially aware community and help church members gain a better understanding of the nature of the Christian life and the character of God. Consequently, it is highly recommended that those who seek to help trauma-sufferers consider the importance of lament in their ministries. As they then put the theory into practice, those who for so long have felt isolated or misunderstood in the Church will find solace and find healing for their pain.

Intradisciplinary and/or interdisciplinary implications: This study challenges current practices in the Church and provides practical applications of the notion of lament, which over the last 20 years has gained much traction in practical theology and biblical studies. Proven empirical studies show how lament can help individuals and the community to find healing.

Keywords: lament; community; trauma; psalms; healing; pastoral ministry.

\section{Introduction}

Lament was an important part of Israel's history, and the Hebrew Bible includes individual and communal laments as an integral part of the relationship with God (Westermann 1981:263). It is a way for a person or group experiencing some deep pain or sorrow to move towards God, even if God may seem to be the cause of the suffering (Westermann 1981:273). Essentially, lament is the means that God has provided to allow those in covenant with God to maintain and deepen that relationship when experience does not match belief (Ellington 2008:14).

In this article, attention is first given to lament in the Old Testament and then the New Testament, to give a biblical basis for this practice. Thereafter, some examples of application in today's world will be reviewed as important means of bringing grace to those in pain.

\section{Lament through the Old Testament and the New Testament}

In the Old Testament, God was seen as the one who could remove suffering, and thus it was normal to bring pain to God. Similarly, when the community experienced a crisis (e.g. the destruction of Jerusalem), they united their sorrow in communal laments (e.g. Ps 79), which were passed on from one generation to the next. Even those who had not been present at the time of the remembered disaster continued to use these laments when they experienced other disasters. There was an ongoing expression of pain to God as people tried to understand how their covenant God could allow certain things to happen.

The Book of Psalms has many laments, both personal and communal. Indeed, one-third of the psalms are laments (O'Connor 2002:9), being more in number than psalms of praise. Apart from psalms, there are many other laments in the Bible. The Book of Lamentations is a very pertinent example of lament, and has much to teach us. So too the Book of Job, with Job's honest interaction 
with God, refusing to accept untruth (from his 'friends') but wrestling to hold in tension his beliefs about God with his experience of God.

In the New Testament, Jesus' lament on the cross (when he quoted from Ps 22, a lament psalm) is a marvellous example of the need to lament, even with the knowledge of eventual victory. He accepted lament as the language of suffering, and granted it both validity and dignity. Moreover, Hughes (2000:193) showed how Jesus' cry on the cross, 'My God, why have your forsaken me?' (Mk 15:34), is actually a declaration of the coming of God's Kingdom. Lament recognises that things are not as they should be, voices this in protest and thereby helps to bring God's Kingdom to earth.

Lament in the New Testament shows some variance with that in the Old Testament. The basic elements of lament continue, that is, it is a cry of pain from the sufferer to God, and it includes complaints, requests (some of which may have to do with justice being meted out to the enemy) and affirmations of faith. Although the New Testament teaching includes 'forgiving the enemy', this is not contrary to 'asking God to mete out justice to the enemy'. The sufferer is able to be free of anger and negative emotion by handing over vengeance to God, and so is able to forgive and to 'bless the enemy'.

Similarly, the New Testament notion of 'enduring hardship' does not preclude complaining to God about it. The lamenter brings the problem to God, along with all the associated emotions (which may also include anger against God), and then trusts God to work it out. Until God resolves the problem, he or she endures. This is what Jesus did on the cross. He voiced his pain at being abandoned, and then endured till the end. It is worth noting that despite being aware of his coming resurrection and return to glory, Jesus lamented (Mat 27:46; Mk 15:34).

\section{Lament in the modern era}

In today's world, lament has been negatively construed in many parts of the Western protestant Church, particularly in Pentecostal and Charismatic churches. Some leaders fear that encouraging prayers of lament will lead to a 'culture of complaint', but as Hamann (2005:139) points out, this is not the case. Rather an opportunity to lament provides people with a tool to deal with the uncertainty and fear that they face. Moreover, as Hamann notes, communal lament provides a necessary antidote to the individualism of our age.

Without leadership encouraging biblical lament, Christians often view despair and anxiety in their own lives as a lack of faith and so fail to express it (Cilliers 2007:396). Popular teaching in the modern church often suggests that praise is good, and lament (or what is understood by 'lament') is bad. It is assumed that one should always be giving thanks, or suffer in silence, without complaint. This erroneous thinking, evident in a lack of the practice of lament, has seriously impacted four areas of church life:
- the well-being of the afflicted

- the depth of relationship and care in the wider community

- people's perception of the character of God

- expectations regarding the nature of the Christian life.

\section{The afflicted}

Those suffering are expected to endure without complaint, resulting in a lack of care and help being extended to many in need (Soelle 1975:36). Those 'not suffering' (living more comfortable lives) try to avoid suffering or loss at any cost. If such persons do experience pain, they usually simply exit the difficult relationship or circumstance (Soelle 1975:40). Thus, the 'more comfortable' often have a smaller experience of pain as well as a smaller capacity to endure pain, and consequently a blindness to the pain of others. Part of this blindness is apparent in the Church, in the way texts are selected for preaching and studying (Ferris 1992:1; O'Connor 2002:135). Those Scriptures dealing with painful personal and social loss are usually sidelined. Sunday readings (or even daily liturgical readings) rarely include laments. And, Lamentations usually get a hearing only in occasional funeral services. Indeed, texts which speak of 'the hiddenness, ambiguity and negativity of God' are avoided, although it is these images of God, held in tension with others, that are necessary if we are to make sense of reality (Cilliers 2007:397).

\section{The wider community}

A second consequence of the lack of lament is a negative impact on the wider community. Soelle $(1975: 4,36,19,103)$ observed that if people minimise their own suffering (through suppressing or ignoring it), they will deal with societal suffering in the same way, resulting in the community becoming progressively toxic. Soelle (1975) commented:

This toleration of exploitation, oppression, and injustice points to a condition lying like a pall over the whole of society; it is apathy, an unconcern that is incapable of suffering. (p. 36)

The sufferer is left to suffer alone. Society becomes progressively more self-centred, relegating all suffering to something 'beyond our influence'. But our inaction serves to justify injustice and oppression. This situation cannot continue. Indeed, 'As long as there is any form of suffering whatsoever, the church needs to beat with an aching heart against God's heart' (Cilliers 2007:395). For the truth is that God is lamenting the injustices of this world (Capps 1981:74), and God waits for us to voice them, and so effect change.

\section{The perception of God}

A third consequence of the lack of lament is that God is seen as one who is sadistic. Suffering is understood as a test from God (a refining or a punishment), to bring us back to a God who only becomes great when others are made small (Soelle 1975:19, 22).

Expectations of the Christian life: To fail to express pain as part of the normal Christian life can result in 'yes-men 
and women', who, when faced with traumatic situations, may simply deny God and cut themselves off from God (Boda 2008:81; Westermann 1981:267).

\section{Benefits of lament}

\section{Social and spiritual benefits}

Given these problematic views that arise when lament is ignored, there has been a resurgence of interest in lament studies over recent years. Since the $1970 s,{ }^{1}$ Westermann has emphasised that the Church needs not only praise but also lament. Since then, many scholars have made significant contributions in the area of lament studies (e.g. Ackermann 1996; Bail 1998; Boase 2016; Broyles 1989; Brueggemann 1986, 2008; Cilliers 2007; Mandolfo 2002; O'Connor 2002; Villanueva 2008; West 2008, 2016). Also, research in trauma studies has grown significantly since the 1990s (see Frechette \& Boase 2016; Herman 1992) linking trauma studies with biblical studies. Advances in cognitive psychology (see Brewin \& Holmes 2003) and neuro-therapy (e.g. Cozolino 2002) have also intersected with biblical studies, suggesting that the practice of lament may contribute to social, spiritual and physical healing.

How then does lament correct the erroneous views mentioned above?

Firstly, with regard to the needs of the afflicted, the painbearer is given the opportunity to tell his or her story. The first step in trauma healing is for the victim (who was treated as an 'object') to be a 'subject' and recover agency, that is, able to make choices (Herman 1992:134). Moreover, the person needs to have his or her pain acknowledged. For someone to take time to recognise that 'I am hurting' is enormously liberating. Indeed, it is vital that the sufferer knows that he or she is heard and no longer alone (Jones 2003:277). The transformative power of a lament is not so much that the person is given answers but rather that, as he or she remembers and relates the suffering, he or she experiences that suffering again in the context of having a hearing (Hamann 2005:123; my emphasis added).

Secondly, with regard to the need for a healthy community, the practice of lament enables Christian witness today to be authentic. For as Wenig (2003:395) asks: 'How can we sing "He makes me lie down in green pastures" when Salvodorean earthquake victims lie trapped under rubble?' Or we might ask: 'How can I not weep when I hear of children on our doorstep becoming physically deformed from sniffing glue, children with no-one to care for them?' What does Paul mean when he instructs the church to 'weep with those who weep' ( $\mathrm{Rm} 12: 15)$ ? If we are to become a community that cares, there is a need for a 'listening attitude' (Hamann 2005:83), offering one's presence and one's ears to those in pain.

Thirdly, lament enables us to face realities in an honest way, correcting wrong ideas of the Christian life. Lament helps a person understand that problems in the Christian life are not to be perceived as signs of failure but as normal and to be expected. As Moltmann $(1974: 7,14)$ wrote, Christ dies 'as one abandoned by God', who on the cross enters into 'the situation of man's God-abandonedness', a situation that is not abnormal to the human condition.

In the early church, when life was hard, many Christian songs had the character of laments. We need to utilise this powerful form today to face the hardships that we all experience, personally and communally. As Ackermann (cited in Paterson 2005) noted:

The scriptures have given us a language that can deal with suffering. In the ancient language of lament, we have a way of naming the unnameable and crying out to God and naming situations that are unbearable. (p. 14)

Cilliers (2007:396) agrees: 'We need to retrieve the language of lament if we hope to find the language of hope'.

Fourthly, with regard to correcting the wrong views of God, lament resists a false view of God that presents a comfortable theology but one that ignores pain. As Moltmann (2015:281) reminds us, 'The true God is not recognized by his power and glory in the world, but through his helplessness and his death on the scandal of the cross of Jesus'. Suffering, and Jesus being abandoned by his Father, is central to Christian theology (Moltmann 1974:7). Indeed, 'the suffering of Christ [is] the power of God' (Moltmann 2015:312).

The practice of lament can help avoid a shallow, onedimensional understanding of the character of God. For example, lament reveals that God is not complacent about suffering, God is not restricted to a dualistic system of retributive justice, God does not view complaint as a lack of faith or hope and God allows Godself to be criticised. The complainant discovers that God engages with him or her as he or she complains but does not rebuke or crush him or her. Instead, 'pain voiced and processed' becomes the basis of a new relationship with God, one that is more mature and able to process difficulty.

Given, then, that lament has a vital role to play in the life of the Church, how can such a practice be implemented, and become a part of normal biblical worship? As Hamann (2005:122) noted, a study of lament psalms can indicate a pattern for biblical lament, and it is this strategy which is adopted in the empirical study.

\section{Physiological benefit of lament}

Apart from the social benefits of the practice of lament, there are also physiological benefits for the lamenter. The experience of trauma causes an overstimulation of hormones in the hippocampus (in the right side of the brain). As a result, the trauma memory is not processed (converted into an episode in one's autobiography and stored in long-term memory). Instead, it is left as 'raw memory'. This leads to the collapse of the 'implicit self' (the sense of knowing 'who I am'), resulting in a loss of feeling safe and being able 
to trust (Schore 2009:126). Moreover, as the trauma memory is not stored as an event in the past, it is continually re-lived, in the present, through intrusive flashbacks.

Lament can help deal with the processing of the trauma memory and restore a sense of trust in the sufferer. Various neuro-researchers (e.g. Cozolino 2002:24; Doidge 2007; LeDoux 2002:8, 56; Schore 2009:142) claim that 'Moderate levels of stress [or stimulation] ... in a positive interpersonal situation' can promote the release of hormones that enable brain stem cells to replace those cells destroyed during trauma, and thereby enable the trauma memories to be properly processed (Schore 2009:140). Such a level of positive stimulation is achieved when one learns something new, particularly when it calls for the use of the imagination. ${ }^{2}$ I argue that such stimulation can be provided by composing and performing one's own lament in the context of a sympathetic audience. Moreover, the right brain (where the healing takes place) is associated with religious experiences (Hug 2007:234), and thus the exercise of studying biblical psalms and composing one's own lament can be expected to promote healing of the soul (see Lyon 2010:238).

Another benefit of using psalms to promote healing following trauma is that poetry uses powerful picture-language (metaphors), which can replace and counteract the toxic trauma memory. For example, images of God as a 'rock of refuge' or 'the true royal lion' (an image suggested by a Zulu poet, in contrast to 'the enemy' making the noise of a common lion) can be helpful to someone overcome by fear.

\section{Aims of this study}

This study seeks to apply the principles of lament in the pastoral context. Many scholars have highlighted the need for the practice of lament (as indicated in the material above) but little has been done empirically in the way of using the biblical text to help people express their pain and find healing.

\section{Ethical considerations}

Ethical clearance to conduct this study was obtained from the Research Department of the University of KwaZulu-Natal (Ethical Clearance number: HSS/1602/015D).

\section{Empirical study: Research methods, results and discussion}

In designing the empirical study, the following principles were noted:

Firstly, the psychotherapist Herman (1992:155) noted that a vital part of recovery for those who have suffered trauma is for the sufferer to have an opportunity to give his or her version of what happened. Towards this end, the (biblical) literature can be very helpful: either texts can provide the words to help a sufferer express his or her story, or the person can create his or her own story (or poem), using a model found in the Bible. The psalms are

2.Interpersonal abuse destroys the person's confidence to be creative. But the capacity is still there to be encouraged. See Hug (2007:232). particularly helpful in this regard as they are full of emotion and so enable the sufferer to deal with the emotive elements of pain.

With regard to the first use of psalms, it is recognised that it is very difficult for a person who has experienced trauma to find the language to express his or her pain. Calvin observed this and thus encouraged sufferers to listen to biblical laments and to mimic their words (Poser 2016:280). Sampson also notes that 'God has given us the biblical language and practice of lament as a way to express our pain and survive our suffering'. Many people through the ages have found a 'voice' in this way. Reading the emotions and prayers within the lament psalms can help sufferers see their situation in a different perspective. This is best done in a public space, with others who either share their suffering or are committed to the sufferers (Soelle 1975:74). It is also necessary that the space and time be 'sacred' (Hamann 2005:121), set apart from the ordinary, and that there is a sense of 'safety' for all participants (with confidentiality a key element). ${ }^{3}$

Secondly, psalms can be particularly helpful in providing words for sufferers as the pain is usually described generally, allowing the reader to fill in the particular details. Thus, the psalms allow for a 'companionship of feelings' (Hamann 2005:124). As the reader identifies with the powerful emotions within a psalm of lament, transformation and healing can result. Also, they often name the perpetrator, which can be very liberating for those who have been physically abused (as assailants often force their victims to remain silent). Bail (1998:242) noted, 'The wall of silence which keeps a victim an isolated prisoner is broken down by naming the violence'. For example, through identifying with the speaker of Psalm 55, abused women can find words for their pain, and regain strength and identity.

Thirdly, poetry (as provided by psalms) is particularly helpful at times of disorientation as it does not require coherence and closure. Many of the lament psalms also include thanksgiving or words of hope. Such sparks of light in the darkness can help sufferers move forward in their lives (the third aspect of healing ${ }^{4}$ ). The pain may not disappear and the oppressor may still be active, but hope returns. This happens not because evil has been explained or the situation has been resolved, but because he or she has been able to focus on the goodness of God, and the relationship with God has been re-established. Hope is stirred as the pain-bearer recognises that 'the current situation is not all that God has

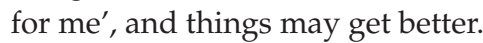

With these notions in mind, it was noted that the psalms can be used in two ways, to facilitate healing for trauma-sufferers. The section below discusses the first of these approaches, using text to provide a voice for those who battle to express their pain.

3.Frechette and Boase $(2016: 16)$ noted that throughout the ages, ritual has been the major means for people to identify with and appropriate, biblical texts. Ritual is major means for people to identify with, and appropriate, biblical texts. Ritual is understood as performance enacted in spaces and times set apart from the ordinary. It is of vital importance to ensure that the ritual space for this activity is
safe and that participants create a sense of solidarity'.

4.The first step is to provide a sense of security, the second to allow the suffere 4.The first step is to provide a sense of security, the second to allow the sufferer
to tell his/her story and the third to connect with life going forward (Herman 1992:155). 


\section{Careful reading of 'lament texts' in a supportive group}

Various scholars have used biblical texts of lament to find hope or healing for contemporary trauma. For example, Brueggemann (1984) noted that Psalm 109:

[C]ould be the voice of a woman who is victimized by rape ... It could be the voice of a black in South Africa who has yet again been brutalized or humiliated by the system. Or it could be a Palestinian peasant weary of war, resentful of displacement. (p. 87)

Other texts that have been useful to give sufferers a voice are Psalm 55 (Bail 1998) and 2 Samuel 13 (Tamar Campaign 2007), both used to help rape victims, and Job 3 (West 2016), used to help victims talk about their traumas and be validated. Similarly, with regard to the AIDS epidemic, Stone (1999) noted:

The presence in most of the laments of both a radical recognition of pain and suffering, and a willingness to hope that things can be otherwise, contributes to the potential value of laments. (p. 26)

In this study, I used Psalm 55 with two different groups in Capricorn, a poor township of Cape Town. ${ }^{5}$ The first group consisted of four young women (a support group for those battling drug addiction) and the second group of 13 women and three men (members of a Bible study group). We started by reading the psalm carefully as a group (using the Contemporary English Version [CEV]). Then, each person took time to re-read it alone, and to underline those verses with which they resonated. It was clear that the psalm provided a 'voice' for their complaints, petitions and the hope they clung to. In Appendix 1, the CEV translation of Psalm 55 is given, and alongside each line is an indication of the kind of speech represented by that statement. Only two of the verses in the psalm comprise requests, nine verses include complaint, five verses express trust in God and three verses address justice issues.

When I conducted the study with the four young women in the support group, they all included requests among the verses with which they identified. The woman whose background and the current situation are possibly the most 'broken' resonated not only with eight of the nine complaints but also with four of the five statements of trust. One identified with two verses of complaint and another with only one. All of the women had resonance with at least one verse affirming trust (either v.16 or 18).

None of the women really identified with the 'city' described in the psalm, not seeing their township as similar (although I even used the name of the township in one of my readings of the psalm). For them, the pain is clearly a personal kind of pain, being betrayed by a friend, rather than the situation of the crime and the danger of living in that community. The results with the Bible study group were similar: of the 16 respondents, 15 resonated with complaint statements, 14 with justice issues, 11 with requests and 12 with affirmations of 5.Ethical approval for the empirical research has a protocol reference number HSS/1985/016PD from UKZN. trust. In both groups, those who resonated most with complaint statements also identified most with affirmations of trust. This supports the notion that lament (bringing complaint to God) is not showing a lack of faith but rather the opposite: Trust in God's goodness encourages them to bring difficult situations to God.

Also, it would seem that the greater the trauma in one's life, the more one identified with the 'lament' in the psalm. This is in line with the assertion of Ellington (2008:11, 30) who maintains that laments are uncomfortable for listeners whose lives are 'in balance'. Many of us could learn much from those in pain who freely admit their helplessness and embrace uncertainty.

\section{Using psalms of lament to compose one's own lament-prayer (in a group)}

Many people value the opportunity to be creative and write their own prayer, specific to their circumstances. In terms of lament-prayers, it is helpful to study several biblical laments to learn the kind of language that God accepts, and the general content of such laments. As Brueggemann (1984) notes, it is the form and structure of lament psalms that facilitates the grieving process. The main elements of biblical lament, as listed by Brueggemann, are an address to God, complaint(s), confession of trust, petition and sometimes a vow of praise.

To help sufferers compose their own laments, I have conducted 'lament workshops' in which we first study Psalm 3 and Psalm 13, two short but helpful lament psalms. Participants note that the psalmist is bold in bringing complaints to God. No kind of language seems to be out of bounds, as long as it is sincere. Raw honest emotion seems to be acceptable. They note, too, that there are requests for God to do various things (to resolve the problem) and also there is often a request for God to deal with the person who caused the pain. Participants note, too, that most lament psalms also include affirmations of faith or some glimpses of hope. ${ }^{6}$ Moods seem to swing from one kind to another, for example, lament to hope, or remembrance of something good that God has done followed by complaint again. ${ }^{7}$

Participants then considered the following questions:

- Is there something that is upsetting me that I would like to complain to God about (a problem with others, God or myself)?

- What would I like to ask God to do in my situation?

- Do I feel a need for justice? Do I need to ask God to 'sort out' the person who caused me trouble?

- What things do I know about God, or have experienced from God in the past, which give me hope at this time?

6.These observations line up with the elements of a lament psalm', which Brueggemann lists (mentioned above).

7.The mood swings in the psalms of lament have been studied with great insight by Villanueva (2008).

8.Capps (1981) suggested a similar list. He proposed that persons writing their own laments should include all the emotions of their complaint, ask God what they need, think of how/why they can trust God and offer a vow of praise (that they will return thanks). 
With their responses to these questions in mind, participants then composed their lament-prayers. They were encouraged to break out of the confines of 'biblical language' or 'prayer language' and to express their real emotions, hopes, fears and pain. ${ }^{9}$ I conducted this kind of study with a number of groups. These are described next.

\section{Using lament psalms to write one's own lament}

One group with which I worked consisted of eight young, unemployed women from an AIDS-support group. They meet weekly in a community hall in Howick (near Pietermaritzburg) and occasionally the University of KwaZulu-Natal provided some positive intervention (in line with a memorandum of understanding agreed between the parties). One woman from this group wrote the following lament:

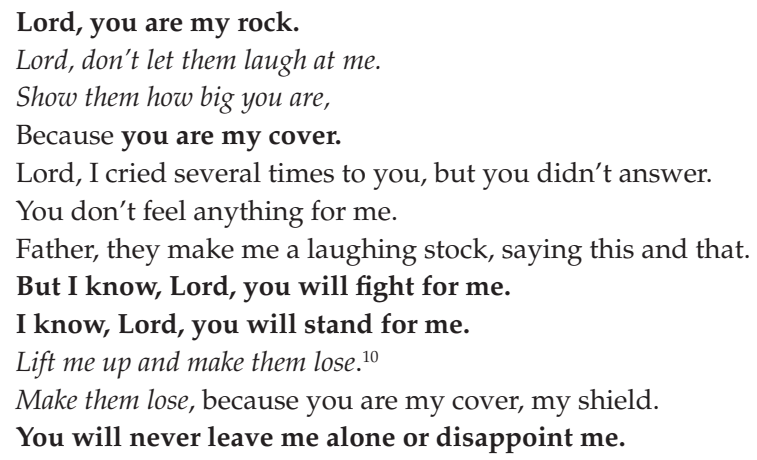

The composer of this prayer complains and takes control of her situation (the words in normal font), thereby asserting her agency. She insists on her right to justice (indicated by italics), and affirms words of faith (shown in bold), which helps her to move forward positively.

Her use of metaphors (God as her rock, her cover, her shield and the one who fights or stands for her) give powerful images that will displace any negative ideas she has of her enemies overwhelming her. The use of repeated statements affirming God's stability (thereby providing her with stability) interspersed with complaints or requests for justice contributes to the 'moderate stress', which promotes the development of healing neurons (as referred to previously).

The reference to 'laugh' in line 2 reminds the composer of the trauma she had experienced. Juxtaposed with this toxic memory is the new image of God being big, thereby displacing the negative emotion associated with the trauma, and bringing a sense of comfort (through God's bigness protecting her). Thus, the lament incorporates many features that promote healing. And being a prayer, it engages divine help!

\section{Using the Lord's Prayer to compose one's own lament-prayer}

The Lord's Prayer is the model that Jesus gave his disciples for all prayers. Although it is not a formal lament, it does

9.Goldingay (1993:12) claimed that the psalms of lament invite us into "an extraordinary freedom in our speech with God'.

10.The explanation given by the poet was this: Let them lose the wrong idea that I am a loser. offer a pattern for lamenting between 'the now' and 'not yet' when God's Kingdom will come in its fullness (Eklund 2012:239). Sampson observes that we need a prayer that will 'create a pathway between the Already and the Not Yet ... that minds the gap between current hopelessness and coming hope' and such a prayer, he claims, is lament. The Lord's Prayer does seem to be particularly appropriate as its central request is 'your kingdom come, your will be done', prayers for the consummation of God's rule that has already begun.

The Lord's Prayer also includes the typical elements of lament: An address to God; opportunity to express complaints, request and affirmations of faith; and elements dealing with justice issues. Thus, I invited two groups in Capricorn to use the Lord's Prayer as a template for their own personal lament-prayer. These were the same two groups as previously, namely, the four women in a support group, and the 16 members of the Bible study group. Each participant was given an outline of the prayer (see Appendix 2), with questions under each heading, to help them compose a prayer item.

Some of the responses of the workshop participants are included in the prayer below.

Complaints have been underlined, to give focus to these elements, typical of lament.

Father,

You are my father because you made me.

Lord, I love you. And I'm glad that I can call you my father. You are the best father.

hallowed be your name.

We do not see your name being honoured in South Africa.

Lord, you are holy.

We do not see God's name being honoured in the church. God is not being honoured by some of my friends. We do not see your name being honoured in our schools.

Your kingdom come.

Babies are thrown away like trash. Please help us! People try to take blessing for themselves (greed). There is too much violence. We ask you for protection. Many don't fear God. They drink every week and live in sins. God is not being served as king at my neighbour's house. God is not being served as king in Parliament.

Give us each day our daily bread,

Please, Lord, look after my child well. Yes, Lord, I do need your food. Money for rent. Electricity.

Lord, we need love and understanding.

Lord, give us spiritual food in our land.

Please make our roads level (no potholes).

I ask, Lord, for the cleansing of our street. 
and forgive us our sins,

I did a lot of things wrong. I know you can forgive me.

I did wrong to my sister many times, and I feel so sorry.

There are long-past sins that still trouble me.

I have failed you in my mind and thoughts.

Forgive my sins with my wife and children.

I am angry at my son-in-law.

for we ourselves forgive everyone who is indebted to us.

I need to forgive people that hurt me although it is tough.

Lord, bring healing in our relationships.

I am angry about my daughter and husband.

People who are very close to me [have wronged me and I feel angry about them].

And lead us not into temptation.

Please help me to not watch too much TV.

I have troubles at home that are getting in the way of my relationship with you.

Help me to share food.

Keep me from having anger in my heart.

I am too much with wrong friends.

From the communal lament (above), it is clear that the two sections, 'hallowed be your name' and 'your kingdom come', are where many complaints were voiced. These are not personal complaints but communal complaints, typical of a communal lament. The first section 'Father' calls up (for these participants) many affirmations of what the fatherhood of God means to them. However, for those from other communities (e.g. young people who have grown up with no father present), the notion of God as Father may be more problematic and may include a complaint. The last four sections of the Prayer include mainly requests, but some participants included complaints (either direct or indirect). For example, in the section, 'as we forgive others', several people mentioned their anger with particular others who had caused them trouble. This can be seen as a positive element of lament, providing space for people to be freed of their emotions of anger and frustration so that they can then forgive those who have done them wrong.

In terms of dealing with enemies, a part of the Old Testament lament, one notes that the Lord's Prayer provides space for both seeking forgiveness and giving forgiveness. However, the need for vengeance (an aspect of the Old Testament lament) is included in the Lord's Prayer, either in 'give us what we need today' (e.g. peace, a sense of justice) or 'lead us not into temptation' (help us not to take vengeance into our own hands but to entrust it to you). And, as mentioned, the voicing of negative emotions, resulting from wrong done to one, can lead to the positive possibility of forgiveness being exercised towards the wrongdoers.

The empirical prayer also shows implied complaints or 'mentioning of practical difficulties of every-day life' in the section, 'Give us each day our daily bread'. However, the study of lament has shown us that it is acceptable andpossible to protest pain and yet also endure in the
New Testament spirit of long-suffering. And so the participants were encouraged to bring to God their complaints, their lacks and needs, in a spirit of humility (not demanding, but longsuffering until God acts and changes their situations). These complaints and lacks included very tangible physical needs (e.g. food, money for rent, electricity supply, clean roads and potholes fixed) as well as social needs (good conversation) and 'spiritual food'.

Scholars through the years have all noted that the requests in the Lord's Prayer aim not only at personal needs but also at the fulfilment of what God has already begun to display. Thus, this prayer, expressing the pain and personal needs of people living in Capricorn, can also be part of the coming of God's kingdom into that community.

\section{Using lament psalms to compose a communal lament for corporate worship}

Beyond the need for individual lament, Worden (1961) also noted:

If we keep in mind the corporate mentality with which these psalms were written, and our obligation to look beyond our individual selves to the whole body of Christ, we will have little difficulty in making these lamentations a genuine expression of our prayer. (p. 51)

He asserts, too, that lament is necessary in modern society, not only for the sake of the suffering and the health of the community but also for the glory of God's name. In his words (Worden 1961):

As God's church, surrounded by dangers, suffering loss and humiliation, we have the solemn obligation to beg that for the glory of God's name our enemies may soon be destroyed. (p. 196)

One reason why lament is needed in corporate worship is that unhealthy power relations must be revised. Williamson (2008:67) observed that 'In Israel's laments before YHWH, issues of power are always at play'. In the Old Testament, the power play is usually between the community and God, but complaints against a powerful enemy or an unjust system were also often included in lament. In our situation in South Africa, with many unjust power arrangements, there is a need to give voice to such wrongs. One example is the enormous challenge facing those forced to flee their countries and become refugees in South Africa. Many church members (who are citizens) are unaware of such difficulties and blind to the needs of those from, for example, Burundi or the Democratic Republic of Congo (DRC), many of them fellow-believers.

To address this need, for 'insiders' (South Africans) to become more sensitive to the needs of 'outsiders' (refugees), I conducted a workshop over several weeks with a group of eight young men from Burundi and DRC. They learnt about lament, and composed a communal lament, which they then prayed as part of the worship one Sunday morning. Little introduction was given to the prayer, except that I quoted a few Scriptures that refer to us being one Body, and that in 
Christ, 'there is no citizen nor refugee ... but all are one in Christ'. Members of the congregation were invited to come around the refugees as they prayed, to symbolically 'protect' them and pray for them in blessing. Many of the congregation found it a very moving and eye-opening experience. Indeed, all but one ${ }^{11}$ of the 50 respondents to a questionnaire noted that they had found the experience had changed their attitudes and possible behaviour towards refugees.

In contrast with those whose lives are 'in balance', those who accept that their lives are 'out of balance' are more ready to lament. Their acknowledgement of pain enables them to come to God in honesty, based on the security of their covenant relationship with God. However, many of those who are materially well off do not want to disrupt the status quo. Lament speaks too frankly and bears too much of the soul, thereby reminding us that we are all vulnerable. This is a challenge to those of us whose lives have been 'comfortable', and a prod to begin to learn to listen to the pain of others in our midst.

The same kind of 'communal lament' could be made by many other groups in the church who suffer a particular situation, for example, widows, the unemployed, single parents, childless couples and those who suffer depression. The very fact that others in the Body recognise their pain and stand together with them in unity before God in intercession can be very healing, and this can build stronger bonds between fellow-believers.

\section{Conclusion}

O'Connor (2002:xiv, 128) claimed that if we do not practise lament and receive healing for ourselves, then our lives may be barren of ministry; those in pain may be left abandoned, battling 'life-threatening despair'; and our communities may remain broken and riddled with injustice. I would add that our view of God and of the Christian life may also be dangerously shallow, leaving our faith vulnerable to being blown away by winds of trouble.

Although personal lament is important, there is also a need for communal lament, using rituals to allow for the articulation of pain, and public spaces to deprivatise the pain (Brueggemann 1984). Within many church traditions, there is space for communal praise, communal confession of sin and communal intercession. However, why has communal lament disappeared from its place in worship? Has the time not come to restore this much-needed aspect of our faith? Are we to allow those in pain to simply turn away from the Church, finding no place to rest their heavy hearts, or let their tears flow and be supported by their brethren?

The decision is critical, and we need to carefully consider this means of grace and take hold of it, for the good of our communities. Lament can no longer be misunderstood and avoided. Neither is it sufficient to simply discuss its importance. For the past 40 years (since Brueggemann and Westermann in the 1980s), scholars have urged the need for lament. But now it needs to be practised, and in an intentional way. This article suggests a few ways to do so. Undoubtedly, many more effective ways are waiting to be tried, and to be shared, to ensure that the Church can move forward strengthened and enabled to serve others.

\section{Acknowledgements}

The author thanks Ujamaa (associated with the University of KwaZulu-Natal), the women of the Siyaphila support-group near Howick, and the fellowship group in Capricorn township (Cape Town).

\section{Competing interests}

The author declares that she has no financial or personal relationship(s) that may have inappropriately influenced her in writing this article.

\section{Authors' contributions}

This article is solely written by J.F.D.

\section{Funding information}

This research received no specific grant from any funding agency in the public, commercial or not-for-profit sectors.

\section{Data availability statement}

Data are available upon request from the author.

\section{Disclaimer}

The views and opinions expressed in this article are those of the author and do not necessarily reflect the official policy or position of any affiliated agency of the author.

\section{References}

Ackermann, D., 1996, 'On hearing and lamenting: Faith and truth-telling', in H.R. Botman \& R.M. Petersen (eds.), To remember and to heal, pp. 47-56, Human and Rousseau, Cape Town.

Bail, U., 1998, 'O God, hear my prayer. Psalm 55 and Violence against Women', in A. Brenner \& C. Fontaine (eds.), Wisdom and Psalms. A feminist companion to the Bible, pp. 242-263, Academic Press, Sheffield.

Boase, E., 2016, Fragmented voices: Collective identity and traumatization in lamentations, SBL, Atlanta, GA.

Boda, M.J., 2008, 'The priceless gain of penitence: From communal lament to penitential prayer in the exilic liturgy of Israel', in N.C. Lee \& C. Mandolfo (eds.) Lamentations in ancient and contemporary cultural contexts, pp. 81-101, SBL, Atlanta, GA.

Brewin, C.R. \& Holmes, E.A., 2003, 'Psychological theories of posttraumatic stress disorder', Clinical Psychology Review 23(3), 339-376. https://doi.org/10.1016/ S0272-7358(03)00033-3

Broyles, C.C., 1989, The conflict of faith and experience in the Psalms. A form-critical and theological study, JSOT Press, Sheffield.

Brueggemann, W., 1984, The message of the Psalms, Augsburg, Minneapolis, MN.

Brueggemann, W., 1986, 'The costly loss of lament', Journal for the Study of the Old Testament 11(36), 57-71. https://doi.org/10.1177/030908928601103605

Brueggemann, W., 2008, 'Lament as wake-up call (class analysis and historical possibility)', in N.C. Lee \& C. Mandolfo (eds.), Lamentations in ancient and contemporary cultural contexts, pp. 221-236, SBL, Atlanta, GA.

Capps, D., 1981, Biblical approaches to pastoral counselling, Westminster Press, Philadelphia, PA. 
Cilliers, J., 2007, 'Breaking the syndrome of silence: Finding speech for preaching in a context of HIV and AIDS', Scriptura 96, 391-406. https://doi.org/10.7833/ $96-0-1164$

Cozolino, L.L., 2002, The neuroscience of psychotherapy, WW Norton and Co., New York.

Doidge, N., 2007, The brain that changes itself. Stories of personal triumph from the frontiers of brain science, Penguin Books, New York.

Eklund, R.A., 2012, 'Lord, teach us how to grieve: Jesus' Laments and Christian Hope', Doctoral thesis, Duke Divinity School.

Ellington, S., 2008, Risking truth: Reshaping the world through Prayers of Lament Princeton Theological Monograph Series 98, Pickwick Publications, Eugene, OR.

Ferris, P.W. Jr., 1992, The Genre of Communal Lament in the Bible and the ANE, Scholars' Press, Atlanta, GA.

Frechette, C.G. \& Boase, E., 2016, 'Defining 'Trauma' as a useful lens for Biblical interpretation', in E. Boase \& C.G. Frechette (eds.), Bible through the lens of trauma, pp. 1-23, SBL, Atlanta, GA.

Goldingay, J., 1993, Praying the Psalms, Grove Books, Nottingham.

Hamann, J.J., 2005, When Steeples cry: Leading congregations through loss and change, The Pilgrim Press, Cleveland, $\mathrm{OH}$.

Herman, J.L., 1992, Trauma and recovery. The Aftermath of violence - From domestic abuse to political terror, Basic Books, New York.

Hug, E., 2007, 'A Neuroscience perspective on psychodrama', in C. Baim, J. Burmeister \& M. Maciel (eds.), Psychodrama. Advances in theory and practice, pp. 227-238, Routledge, London.

Hughes, R.A., 2000, 'Lament in Christian theology', Encounter 61(2), 187-204.

Jones, S., 2003, 'Soul Anatomy: Calvin's commentary on the Psalms', in H.W. Attridge \& M.E. Fassler (eds.), Psalms in community. Jewish and Christian textual, liturgical, and artistic traditions, pp. 265-284, SBL, Atlanta, GA.

LeDoux, J., 2002, 'Emotions: How I've looked for them in the brain', in R.J. Russell, N. Murphy, T.C. Meyering \& M.A. Arbib (eds.), Neuroscience and the person, pp. 41-44, Vatican Observatory, Vatican City.

Lyon, E., 2010, 'The spiritual implications of interpersonal abuse: Speaking of the soul', Pastoral Psychology 59(2), 233-247. https://doi.org/10.1007/s11089-0090238-2

Mandolfo, C., 2002, God in the dock. Dialogic tension in the Psalms of lament, Sheffield Academic Press, Sheffield.

Moltmann, J., 1974, 'The crucified God', Theology Today 31(1), 6-18. https://doi.org/ 10.1177/004057367403100102
Moltmann, J., 2015, The crucified God, Fortress, Minneapolis, MN.

O'Connor, K.M., 2002, Lamentations and the tears of the world, Orbis Books, Maryknoll, NY.

Odets, W., 1995, In the shadow of the epidemic: Being HIV-negative in the age of AIDS, Duke University Press, Durham.

Paterson, G., 2005, AIDS related stigma. Thinking outside the box: The Theological challenge, Ecumenical Advocacy Alliance and The World Council of Churches, Geneva.

Poser, R., 2016, 'No words: The book of Ezekiel as trauma literature and a response to exile', transl. D.L. Schneider, SBL, Atlanta, GA.

Sampson, A., n.d., Unfolding stories [Podcast], viewed 10 April 2019, from http:// unfoldingfaithblog.com/2019/01/22/lament-what-does-lament-mean/.

Schore, A.N., 2009, 'Right-brain affect regulation', in D. Fosha, D.J. Siegel \& M.F. Solomon (eds.), The healing power of emotion, pp. 112-144, Norton and Co., New York.

Soelle, D., 1975, 'Suffering', transl. E.R. Kalin, Fortress Press, Philadelphia, PA.

Stone, K., 1999, 'Safer texts: Reading Biblical laments in the age of AIDS', Theology and Sexuality 1999(10), 16-27. https://doi.org/10.1177/135583589900501003

Tamar Campaign, 2007, Contextual Bible study manual on gender-based violence, in F. Nyabera \& T. Montgomery (eds.), The Fellowship of Christian Councils and Churches in the Great Lakes and The Horn of Africa (FECCLAHA), Nairobi.

Villanueva, F.G., 2008, The 'Uncertainty of a Hearing'. A study of the sudden change of mood in the psalms of lament, Brill, Leiden.

Wenig, M.M., 2003, 'Mizmor L'David', in H.W. Attridge \& and M.E. Fassler (eds.), Psalms in community. Jewish and Christian textual, liturgical and artistic traditions, pp. 395-402, SBL, Atlanta, GA.

West, G.O., 2008, 'The poetry of job as a resource for the articulation of embodied lament in the context of HIV and AIDS in South Africa', in N.C. Lee \& C. Mandolfo (eds.), Lamentations in ancient and contemporary cultural contexts, pp. 195-215, SBL, Atlanta, GA.

West, G.O., 2016, Between text and trauma: Reading job with people living with HIV, SBL, Atlanta, GA.

Westermann, C., 1976, 'Roep uit de diepte', Concilium 12(9), 57-68.

Westermann, C., 1981, Praise and lament in the Psalms, John Knox Press, Louisvile, KT.

Williamson, R. Jr., 2008, 'Lament and the arts of resistance: Public and hidden transcripts in lamentations $5^{\prime}$, in N.C. Lee \& C. Mandolfo (eds.), Lamentations in ancient and contemporary cultural contexts, SBL, Atlanta, GA.

Worden, T., 1961, The Psalms are Christian prayer, Sheed and Ward, New York. 


\section{Appendix 1 \\ Psalm 55 (CEV)}

${ }^{1}$ Listen, God, to my prayer! Don't reject my request.

request

2 Please listen and help me.

My thoughts are troubled, and I keep groaning

request

${ }^{3}$ because my loud enemies shout and attack.

complaint

They treat me terribly and hold angry grudges.

complaint

${ }^{4}$ My heart is racing fast, and I am afraid of dying.

complaint

${ }^{5}$ I am trembling with fear, completely terrified.

complaint

${ }^{6}$ I wish I had wings like a dove, .

so I could fly far away and be at peace.

${ }^{7}$ I would go and live in some distant desert.

complaint

wish/complaint

wish/complaint

${ }^{8}$ I would quickly find shelter from howling winds and raging storms.

wish

${ }^{9}$ Confuse my enemies, Lord! Upset their plans.

wish

Cruelty and violence are all I see in the city,

justice

${ }^{10}$ and they are like guards on patrol day and night.

complaint

complaint

The city is full of trouble, evil.

complaint

${ }^{11}$ and corruption,

Troublemakers and liars freely roam the streets.

complaint

complaint

${ }^{12} \mathrm{My}$ enemies are not the ones who sneer and make fun.

complaint

I could put up with that or even hide from them.

${ }^{13}$ But it was my closest friend, the one I trusted most.

complaint

complaint

${ }^{14}$ We enjoyed being together, and we went with others

complaint

to your house, our God.

complaint

${ }^{15}$ All who hate me are controlled by the power of evil.

Sentence them to death and

complaint

send them down alive to the world of the dead.

justice

justice

${ }^{16}$ I ask for your help, Lord God, and you will keep me safe.

${ }^{17}$ Morning, noon, and night you hear my concerns and my complaints.

trust

${ }^{18} \mathrm{I}$ am attacked from all sides, but you will rescue me,

trust

unharmed by the battle.

${ }^{19}$ You have always ruled, and you will hear me.

trust

trust

You will defeat my enemies because they won't turn and worship you.

trust

trust

${ }^{20} \mathrm{My}$ friend turned against me and broke his promise.

complaint

${ }^{21} \mathrm{His}$ words were smoother than butter, and softer than olive oil.

complaint

But hatred filled his heart, and he was ready to attack with a sword.

complaint

${ }^{22}$ Our Lord, we belong to you.

We tell you what worries us, and you won't let us fall.

${ }^{23}$ But what about those people who are cruel and brutal?

trust

trust

You will throw them down into the deepest pit long before their time.

complaint

I trust you, Lord!

justice

trust 


\section{Appendix 2}

The Lord's Prayer (with questions to help respondents compose their own prayer). On the right, the speech-type is shown, underlined

When you pray (or lament), say

Father, (relationship of pray-er with God).

address to God, affirmation of faith

Can you call God your Father? Do you have some problems thinking of God as your heavenly father?

Or is it a relationship that means a lot to you?

hallowed be your name. Your kingdom come.

(relationship of world with God)

What aspects of our society and life as a community show a great lack of God being served as king?

Give us each day our daily bread, (our physical needs).

What do I and my family/community lack in terms of resources for daily living?

and forgive us our sins, (relationship of pray-er with self)

What have I done wrong, that is in my heart now?

for we ourselves forgive everyone who is indebted to us.

(relationship with enemies)

Which people have wronged me that I feel angry about?

And lead us not into temptation.

(relationship of pray-er with God)

What is getting in the way of my relationship with God? (Am I angry about something? Or worried?

Or confused?)

affirmation of faith, complaint

request, complaint

request

justice issue, request

request 